\title{
Assessment of in situ-Prepared Polyvinylpyrrolidone-Silver Nanocomposite for Antimicrobial Applications
}

\author{
W. El Hotaby ${ }^{a}$, H.H.A. SheriF ${ }^{a, *}$, B.A. Hemdan ${ }^{b}$, W.A. Khalil ${ }^{c}$, S.K.H. Khalil ${ }^{a}$ \\ ${ }^{a}$ Spectroscopy Department, Physics Division, National Research Center, Cairo, Egypt \\ ${ }^{b}$ Environmental Microbiology Lab, Water Pollution Research Department, National Research Center, Cairo, Egypt \\ ${ }^{c}$ Biophysics Department, Faculty of Science, University of Cairo, Cairo, Egypt
}

(Received March 13, 2017; in final form April 14, 2017)

\begin{abstract}
Polyvinylpyrrolidone (PVP) is employed in several potential applications, relying of its special chemical and physical properties in addition to its low toxicity and biocompatibility. The aim of this work is to prepare polyvinylpyrrolidone-silver (PVP-Ag) nanocomposite with high inhibiting effect on the microbial growth and low cytotoxicity. In situ prepared small stable spherical silver nanoparticles, with narrow range particle size distribution, were obtained by easy, economical and rapid chemical reduction method. Silver ions were reduced to silver nanoparticles using low amount of sodium borohydride $\left(\mathrm{NaBH}_{4}\right)$ as a strong reducing agent. PVP-Ag nanocomposite was prepared using PVP as a stabilizing and capping agent. Formation of the spherical silver nanoparticles with mean particle size $5 \mathrm{~nm}$ was confirmed by ultraviolet-visible spectroscopy, high resolution transmission electron microscopy, and dynamic light scattering. The inhibiting growth effect of the nanocomposite toward Gram-positive bacteria (Staphylococcus aureus), Gram-negative bacteria (Pseudomonas aeruginosa), and yeast fungus (Candida albicans) were studied. The cytotoxicity of the nanocomposite against BJ1 normal skin fibroblast cell line was tested. Results of this work presented perfect antimicrobial activity of the PVP-Ag nanocomposite towards bacteria and fungi with low cytotoxicity, which may lead to promising applications in skin wound healing.
\end{abstract}

DOI: 10.12693/APhysPolA.131.1554

PACS/topics: silver nanoparticles, polyvinylpyrrolidone, nanocomposite, antimicrobial activity, cytotoxicity

\section{Introduction}

In both hospitals and community-acquired infections, the antimicrobial resistance has reached a crisis point, since it became an affecting public health factor throughout the world [1]. The microbial resistance to antibiotics is referred to the fact that the majority of these antibiotics are targeting intercellular components without any effect on the cellular morphology. Therefore, many researchers have been working on developing macromolecular antimicrobial materials that perform the microbial membrane disruption to the microbial membrane; consequently, developed resistance through cell mutation can be avoided [2]. As soon as an individual is attacked by multidrug resistance bacteria (MRD), it is not easy to treat and more time is taken in the hospital. Although this requires high cost treatments with broad spectrum antibiotics, it still has low effectiveness and high toxicity. Thus, it is a priority area of research to develop or modify antimicrobial compounds improving bactericidal potential [3].

For long period of time, different chemical forms of silver have been accepted as effective antimicrobial agents which are highly active against bacteria, viruses and fungi [4-6]. However, a decline in silver medical applications as antimicrobial occurred due to the progress of antibiotics $[3,7,8]$. After that, the era of nanotechnology was

*corresponding author; e-mail: hhasherif@yahoo.com emerged (1-100 $\mathrm{nm}$ ) carrying highly promising properties of the silver for medical applications. At nanoscale, the ultra-small particle size brings about ultra-large surface area per mass therefore direct contact with ambiance is achieved by large number of atoms which are readily available for reaction $[8,9]$. AgNPs have specific properties such as high thermal conductivity and stability [10], and strong shape-dependent optical properties [11, 12]. Furthermore, AgNPs are capable of enhancing the scarless wound healing and cosmetic appearance $[13,14]$. Moreover, AgNPs are considered as one of the most inorganic materials [15].

A variety of preparation methods, namely physical [16], chemical [17], biosynthetic [18] and biological $[19,20]$ approaches have been studied to prepare AgNPs. The solution and solid state AgNPs could be produced by photochemical synthesis [21], laser ablation [22], microwave treatment [23] and $\gamma$-irradiation [24]. The reduction of AgNPs in such physical techniques depends mainly on the supplied activation energy through thermal heating, laser irradiation, ultrasonic, fixed frequency microwave radiation, UV irradiation [25]. On the other hand, the synthesis of AgNPs by biosynthetic and biological methods through the interaction of plant extract, bacteria, fungi, actinomycetes and algae has been widely explored [26]. Although physical and biological approaches have been established to be an alternative to conventional methods, the chemical methods are still more versatile [9].

It is believed that better control of size, shape and monodispersity will lead to enhancement of AgNPs 
production with high precision which would be applied in the various fields [26]. Fortunately, chemical reduction method is chosen to be applied due to its advantages of being rapid, simple and economical way to produce AgNPs with well-controlled size and shape, using reducing and stabilizing agents to prevent these nanoparticles from agglomeration [9]. A soluble silver salts (either in water or organic solvent) is reduced by any of the reducing agents as citrate, ethyl glycol, glucose, or sodium borohydride [27]. Christy et al. [28] prepared Ag NPs by chemical reduction method using $N, N$-dimethylformamide and PVP under ultrasonic field. In chemical reduction method, the redox potential, temperature, concentration of the reactants and additions, and the solvent properties used are controlling factors in the size and particle distribution as well as the antimicrobial activity of produced nanoparticles. Using strong reducing agents (such as $\mathrm{NaBH}_{4}$ ) initiate high reduction rate leading to fast releasing of atoms in the saturated solution. As a consequence, much more nucleation rate occurs at the expense of the particles growth rate. Thus, small monodispersed nanoparticles are obtained and vice versa [29-31]. Addition of stabilizers as natural and synthetic polymers to metal components, using different methods, is used to prevent the coalescence of the nanoparticles [17]. Also, the production of a very narrow particle size distribution with uniformity can be expected. Polymers with certain affinity toward metals such as chitin, chitosan [32] polyvinyl alcohol, polyacrylamide, acrylonitrile, and PVP, are the most used substance for metal nanoparticles stabilization [12]. Considerable attention is drawn to PVP owing to its special chemical and physical properties recommending it as a coating or as additive to different materials [6]. PVP can perform a dual role: first is stability and second is controlling the rate of silver ions reduction and aggregation process of silver atoms [6, 33]. Moreover, low toxicity and acceptable biocompatibility make PVP suitable and promising for medical applications [31].

Consequently, the objective of this work is to prepare PVP-Ag nanocomposite with stable and small AgNPs with narrow particle size distribution for the antimicrobial activity against bacteria and fungi. In situ reduction of AgNPs in room temperature (without any activation energy) using chemical reduction method can be utilized. We also aim to study the optimum condition of the reaction, such as the amount of $\mathrm{NaBH}_{4}$ and $\mathrm{AgNO}_{3}$ solution by using UV-vis spectroscopy. Low amounts of the strong reducing agent $\mathrm{NaBH}_{4}$ can be employed, to decrease the cytotoxicity of the nanocomposite assisting it as a biomedical material. A precise antimicrobial test (colony counting method) and cytotoxicity toward BJ1 normal skin fibroblast cell line can be used.

\section{Materials and methods}

\subsection{Materials}

Polyvinylpyrrolidone PVP (molecular biology grade) $\left(\mathrm{C}_{6} \mathrm{H}_{9} \mathrm{NO}\right)_{n}$ with average F.M. 40,000 was purchased from Fisher, USA. L-ascorbic acid L-A.A. $(M=176.13)$ from ACS. Sodium borohydride fine granules $\mathrm{NaBH}_{4}$ (98\%) was purchased from Merck (Russian Fed.), and silver nitrate $\mathrm{AgNO}_{3}$ extra pure was from SRL (India). Milli-Q water was used during the sample preparation. All the purchased chemicals were used without further purification.

\subsection{Methods}

$100 \mu \mathrm{L}$ of L-A.A. solution of $0.01 \mathrm{M}$ was added to $5 \mathrm{ml} \mathrm{PVP}$ solution $(2 \mathrm{wt} \%)$. The mixture was stirred for 10 min then $X-\mu \mathrm{L}$ of $\mathrm{AgNO}_{3}$ solution $(0.01 \mathrm{~mol} / \mathrm{L})$ was added to the solution under stirring, where $X=10$, $30,50,70,100 \mu \mathrm{L}$. After that $Y-\mu \mathrm{L}$ of $\mathrm{NaBH}_{4}$ solution $(0.1 \mathrm{M})$ was added to the mixture and stirred for $15 \mathrm{~min}$, where $Y=10$ to $70 \mu \mathrm{L}$. The color of the solution turned yellow immediately. For film formation, certain amount of the nanocomposite solution was casted in the Petri dish and dried at $60^{\circ} \mathrm{C}$.

\subsection{Characterization}

Synthesis of AgNPs was initially confirmed by using UV-vis spectroscopy. The absorption spectra were recorded in the range between $200 \mathrm{~nm}$ and $800 \mathrm{~nm}$ using spectrophotometer Jasco V-630, India. The Fourier transform infrared (FTIR) spectra were recorded by BRUKER-VERTEX 70 (Germany) using KBr disc method. X-ray diffraction (XRD) measurement were carried out by X-ray diffraction X'Pert Pro PANalytical (Holland), targeted by $\mathrm{Cu}_{r \alpha}$ with secondary monochromator $(45 \mathrm{kV}, 40 \mathrm{~mA})$. The morphological structure (size and shape) of AgNPs is studied using high resolution transmission electron microscope HRTEM (JEOL-2100). The particle size distribution and zeta potential of the AgNPs stabilized and capped by PVP were characterized by dynamic light scattering (DLS) using a Malvern nano ZS (Malvern instrument Ltd., Worcestershire, UK).

\subsection{Inhibition of microbial growth}

\subsubsection{Microorganisms used and preparation}

Three strains (Staphylococcus aureus ATCC6538, Pseudomonas aeruginosa ATCC15442 and Candida albicans ATCC10231) were cultured in tryptic soya broth (Oxoid-UK) and incubated at $37^{\circ} \mathrm{C}$ for $24 \mathrm{~h}$. After the incubation, the suspensions were homogenized by the vortex and centrifuged at $3000 \mathrm{rpm}$ for $20 \mathrm{~min}$ and washed three times by adding sterile phosphate buffered solution. The density of each strain inocula was $10^{6} \mathrm{CFU} / \mathrm{ml}$.

\subsubsection{Cell viability test}

The antimicrobial effect PVP-Ag nanocomposite was determined against three different microbial strains. The stock suspension of each bacterial strain was previously prepared. Each one of the stock suspension was exposed to four concentrations of PVP-Ag (25, 50, 75, and $100 \mu \mathrm{g} / \mathrm{mL}$ ) at three contact times (60, 90, and $120 \mathrm{~min})$. Cells of $S$. aureus, $P$. aeruginosa and $C$. albicans were incubated with $\mathrm{PVP}-\mathrm{Ag}$ nanocomposite in distilled water 
at $37^{\circ} \mathrm{C}$ under $250 \mathrm{rpm}$ shaking speed. The viability of each tested strains cells was evaluated by the colony counting method according to (APHA, 2012). Colonies were counted, and compared to those on control plates to calculate changes in the cell growth inhibition. All treatments were prepared in duplicate and repeated at least on three separate occasions.

\subsection{MTT cytotoxicity test}

Cytotoxicity of PVP-AgNPs composite was determined by Cell proliferation kit1 (MTT assay) for nonradioactive quantification of cell proliferation and cell viability based on succinate-tetrazolium reductase (Bio Basic Canada Inc., Canada). This enzyme is capable of reducing tetrazolium dye MTT to formazan, turning the color from yellow to purple. A sterile laminar air flow cabinet biosafety class II level (Baker, SG403INT, Stanford, ME, USA) was used for performing all the preceding steps. Cells were incubated in humidified $5 \% \mathrm{CO}_{2}$ incubator at $37^{\circ} \mathrm{C}$ (Sheldon, TC2323, Cornelius, OR, USA). Approximately, BJ1 (normal Skin fibroblast) cells were seeded in 96-well $\mu \mathrm{L}$ plastic plates and kept for $24 \mathrm{~h}$ to adhere. After that, media was aspired and various concentrations (from 100 to $0.78 \mu \mathrm{g} / \mathrm{mL}$ ) of the composite were added to the cells. The cells were then incubated for another $48 \mathrm{~h}$. Media was aspired and for each well, $40 \mu \mathrm{l}$ MTT salt $(2.5 \mu \mathrm{g} / \mathrm{mL})$ were added and incubated for further $4 \mathrm{~h}$. For stopping the reaction and dissolving any formed formazan crystals, $200 \mu \mathrm{L}$ of sodium dodecyl sulfate (10\%) was added and incubated overnight at $37^{\circ} \mathrm{C}$. The formazan amount produced was measured using a microplate reader (Bio-Rad Laboratories, model 3350 , USA) at wavelength $595 \mathrm{~nm}$ with a background reference of $620 \mathrm{~nm}$. As a negative control, wells containing only the cells were used. Whereas the positive control, known as cytotoxic natural agent giving 100\% inhibition, used was Adrinamycin ( $)$ (doxorubicin) $\left(M_{r}=579.9\right)$. Dimethyl sulfoxide (DMSO) was used for dissolution of the tested compounds.

\section{Results and discussion}

\subsection{Ultraviolet-visible spectroscopy}

Investigating the effect of different volumes of $\mathrm{AgNO}_{3}$ and $\mathrm{NaBH}_{4}$ solutions in preparation of AgNPs under constant environmental conditions was carried out by UVvis spectroscopy. It was observed that the color of the mixture changed from colorless to yellow which was considered as the first evidence for the AgNPs formation. Figure $1 \mathrm{a}-\mathrm{g}$ displays the UV-vis absorption spectra of $\mathrm{PVP}-\mathrm{Ag}$ nanocomposites prepared with different volumes of $\mathrm{NaBH}_{4}(10,20,30,40,50,60$, and $70 \mu \mathrm{L})$, respectively. The PVP-Ag nanocomposite spectra of all samples exhibited a single characteristic surface plasmon resonance (SPR) absorption band around $410 \mathrm{~nm}$ which indicates the formation of AgNPs. The appearance of a single absorption band in the range 400-450 nm suggests that the AgNPs is formed in spherical shape [34-37].
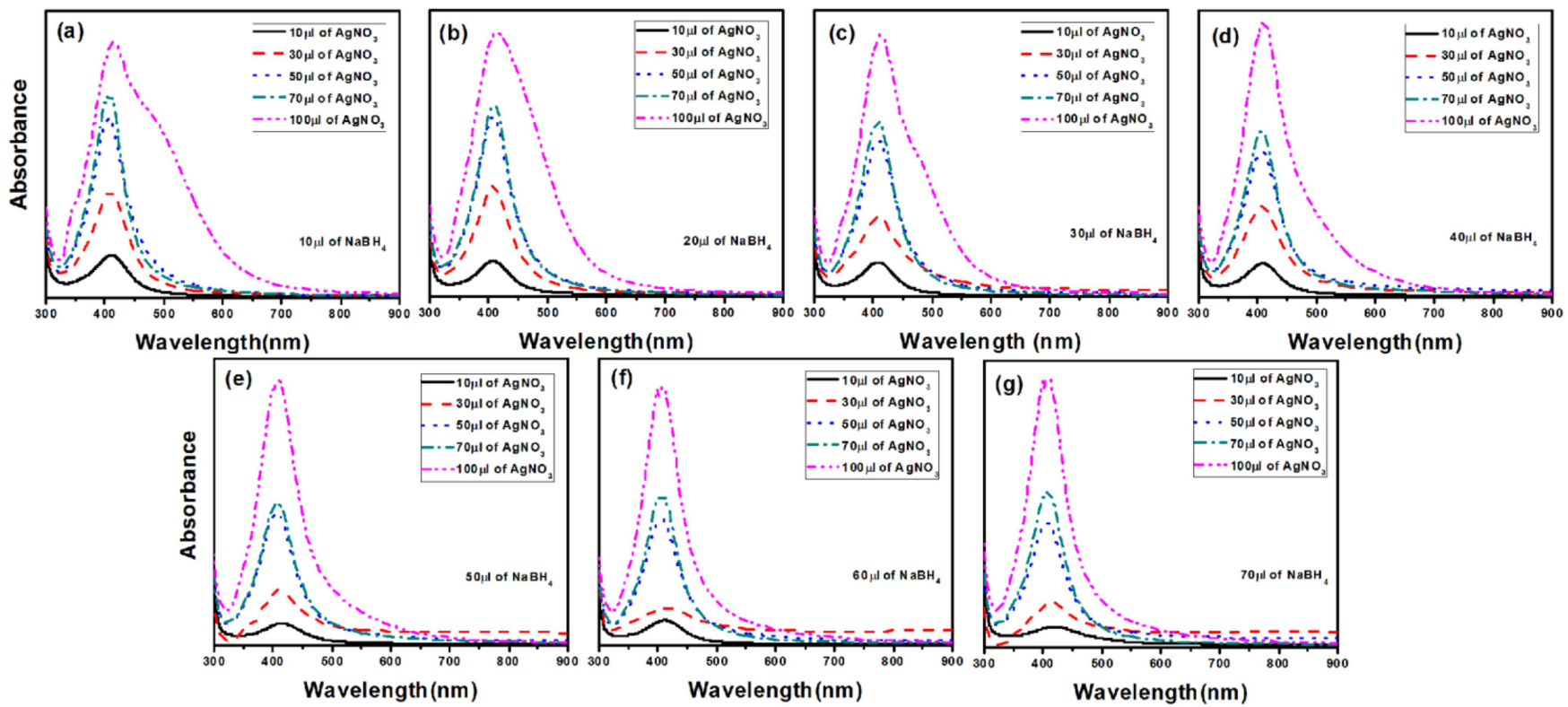

Fig. 1. UV-vis absorption spectra of PVP-Ag nanocomposites prepared with different volumes of $\mathrm{NaBH}_{4}(\mathrm{a})-(\mathrm{g})$ solutions added to specific volumes of $10-100 \mu \mathrm{L}$ of $\mathrm{AgNO}_{3}$ solution.

It also can be noticed that the intensity of SPR band of AgNPs increases with increasing the volume of $\mathrm{AgNO}_{3}$ solution (Fig. 1). For the samples prepared using $100 \mu \mathrm{L}$ of $\mathrm{AgNO}_{3}$ solution, the SPR band Fig. 1a-d showed broadening toward longer wavelength, whereas
Fig. 1e-g showed symmetrical and narrow shape of SPR band. It can be concluded that using little amount of $\mathrm{NaBH}_{4}(10-40 \mu \mathrm{L})$ solution relative to that of $\mathrm{AgNO}_{3}$ $(100 \mu \mathrm{L})$ solution tends to produce polydispersed AgNPs, while adequate amount $(50-70 \mu \mathrm{L})$ produced spherical 
monodispersed AgNPs. This is in consistence with Tran et al. [38], who suggested that prepared AgNPs, using chitosan as reducing agent, were spherical and monodispersed according to the symmetrical and narrow shape of SPR band.

For further examination, the absorbance of the SPR band was drawn as a function of the volume of $\mathrm{AgNO}_{3}$ solution (Fig. 2). It can be observed that for all specified volumes of $\mathrm{NaBH}_{4}$ solutions under investigation, the absorbance increases with increase of the volume of $\mathrm{AgNO}_{3}$ solution till it reaches maximum at $100 \mu \mathrm{L}$ of $\mathrm{AgNO}_{3}$. The lowest rate of absorbance rise is seen for nanocomposites prepared using 10 and $20 \mu \mathrm{L}$ of $\mathrm{NaBH}_{4}$ solution at $100 \mu \mathrm{L} \mathrm{AgNO}_{3}$ solution. This result concedes with that reported by Song et al. [10]. Based on the UV-vis results, the ratio between amounts of $10 \mu \mathrm{L} \mathrm{NaBH} 4$ to $50 \mu \mathrm{L} \mathrm{AgNO}{ }_{3}$ was optimized for further investigations.

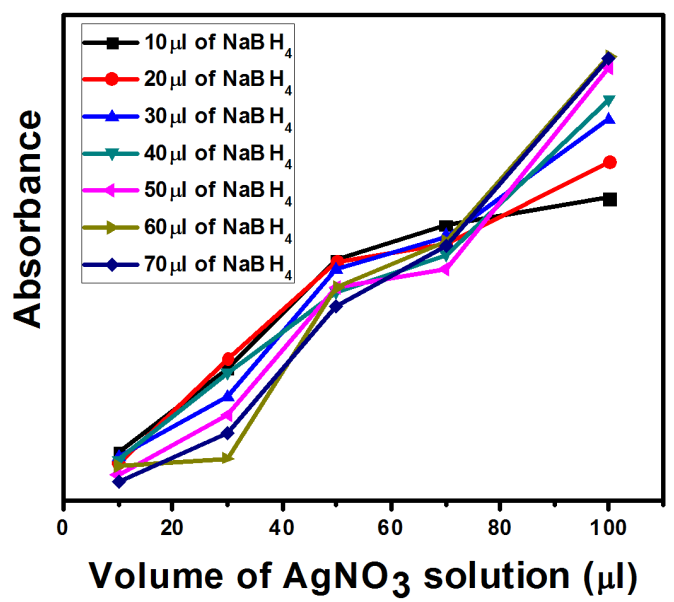

Fig. 2. Effect of the volume of $\mathrm{AgNO}_{3}$ solution on the intensity of the produced PVP-Ag nanocomposite SPR band.

\subsection{X-ray diffraction}

The XRD pattern of pure PVP (Fig. 3a) showed two broad characteristic peaks at $2 \theta$ of $11.25^{\circ}$ and $21.21^{\circ}$ corresponding to $d$-values of 7.7826 and $4.1844 \AA$, respectively. This is in good agreement with results reported by $\mathrm{Li}$ et al. [39]. The XRD pattern of $\mathrm{PVP}-\mathrm{Ag}$ nanocomposite film showed two $2 \theta$ of $10.77^{\circ}$ and $21.61^{\circ}$ corresponding to $d$-values of 8.2129 and $4.3096 \AA$, respectively. This finding can be due to the very low concentration $(0.01 \mathrm{M})$ and amount $(50 \mu \mathrm{L})$ of the $\mathrm{AgNO}_{3}$ used in the composite preparation, in one hand, and the PVP masking to the nanoparticles, in the other hand.

\subsection{Fourier transform infrared spectroscopy}

Figure 4a,b represents FTIR spectra of PVP and PVPAg nanocomposite, respectively. The spectra showed a broad band at $3441 \mathrm{~cm}^{-1}$ due to $\mathrm{OH}$ stretching vibration. A medium peak and a weak shoulder appeared at $2955 \mathrm{~cm}^{-1}$ and $2893 \mathrm{~cm}^{-1}$, respectively, which are corresponding to symmetric and asymmetric stretching vibrations of $\mathrm{CH}_{2}$, respectively [40, 41]. A strong

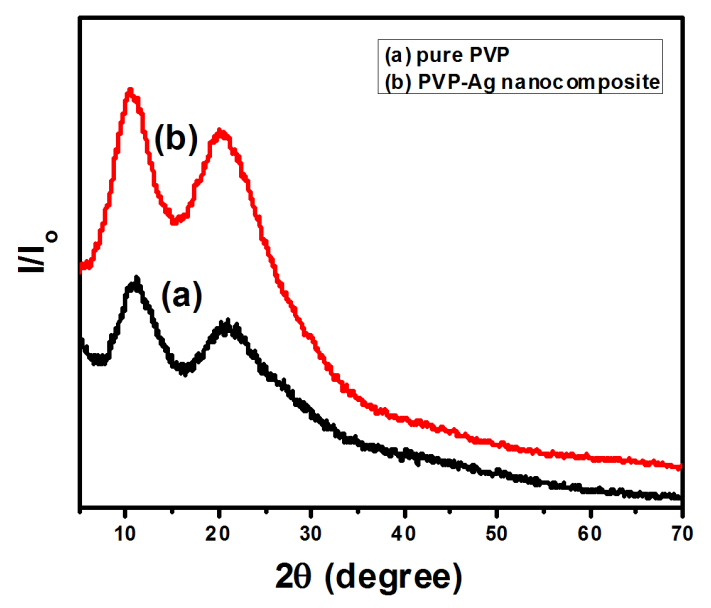

Fig. 3. X-ray diffraction pattern of: (a) pure PVP, (b) $\mathrm{PVP}-\mathrm{Ag}$ nanocomposite film (prepared by $50 \mu \mathrm{L}$ of $\mathrm{AgNO}_{3}$ solution and $10 \mu \mathrm{L}$ of $\mathrm{NaBH}_{4}$ solution).

sharp peak ascribed to $\mathrm{C}=\mathrm{O}$ stretching vibration appeared at $1663 \mathrm{~cm}^{-1}[42,43]$, followed by four medium peaks at $1495,1462,1439$, and $1423 \mathrm{~cm}^{-1}$ which could be assigned to scissoring vibration of $\mathrm{CH}_{2}$ group. $\mathrm{CH}_{2}$ wagging vibrations and $\mathrm{C}-\mathrm{N}$ stretching appeared at $1318 \mathrm{~cm}^{-1}$ and $1290 \mathrm{~cm}^{-1}$, respectively [44, 45]. $\mathrm{CH}_{2}$ twisting and rocking vibrations appeared at $1229 \mathrm{~cm}^{-1}$ and $1018 \mathrm{~cm}^{-1}$. Comparing with PVP spectrum, the spectrum of PVP-Ag nanocomposite (Fig. 4b) showed no change in the spectral features which may be due to the small amount of AgNPs present in the sample. This observation supports the results obtained from XRD.

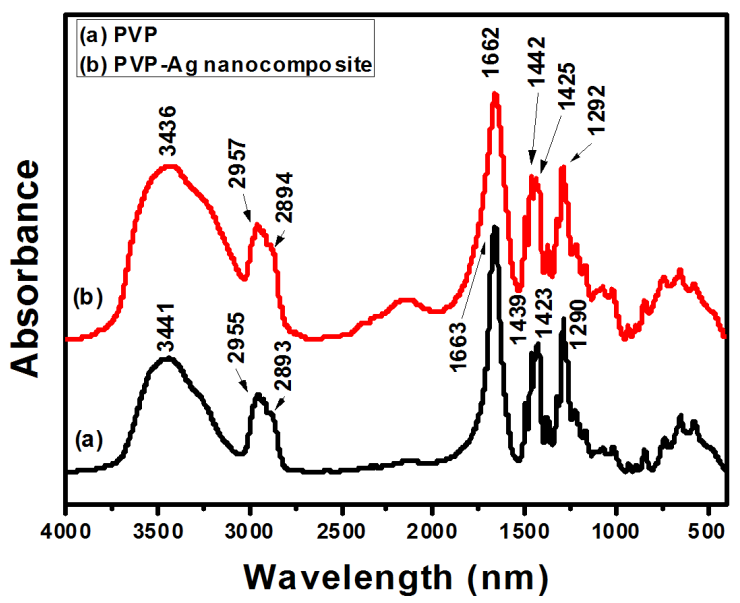

Fig. 4. FTIR spectra of (a) PVP, (b) PVP-Ag nanocomposite (prepared by $50 \mu \mathrm{L}$ of $\mathrm{AgNO}_{3}$ solution and $10 \mu \mathrm{L}$ of $\mathrm{NaBH}_{4}$ solution).

\subsection{High resolution-transmission electron microscopy}

The HRTEM was used to study the morphological structure (size and shape) of the AgNPs in freshly prepared sample of $\mathrm{PVP}-\mathrm{Ag}$ nanocomposite (Fig. 5a). 


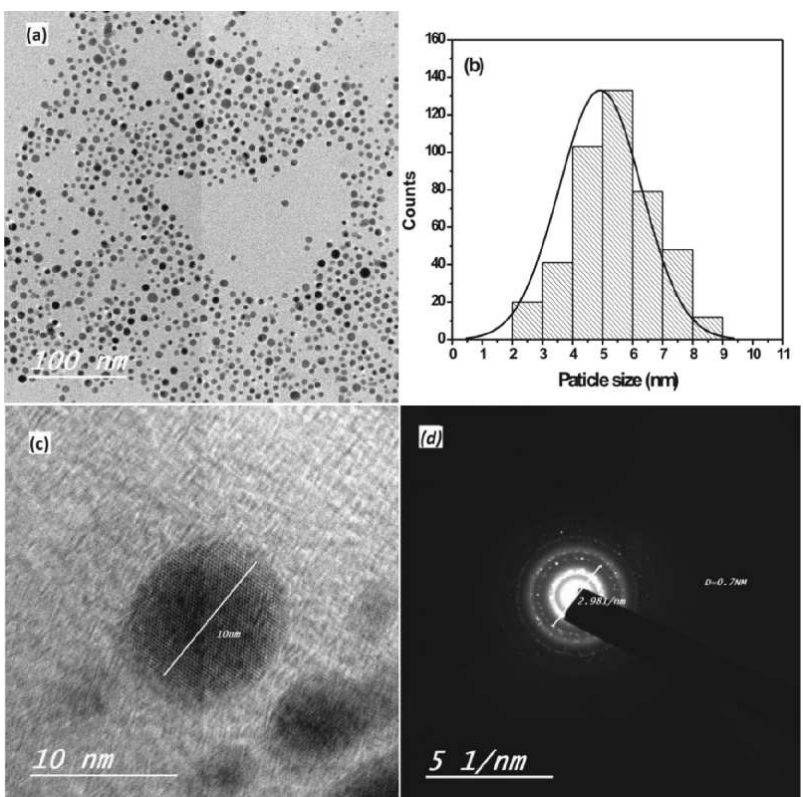

Fig. 5. HRTEM analysis: (a) image of PVP-Ag nanocomposite (prepared by $50 \mu \mathrm{L}$ of $\mathrm{AgNO}_{3}$ solution and $10 \mu \mathrm{L}$ of $\mathrm{NaBH}_{4}$ solution), (b) particle size distribution of AgNPs in PVP-Ag nanocomposite with Gaussian fitting curve, (c) image of particle crystallinity of AgNPs, and $(\mathrm{d})$ diffraction pattern of the AgNPs.

The AgNPs are very small, spherical and loosely distributed in the polymer. The histogram shown in Fig. 5b represents the particle size distribution analyzed in the TEM micrograph (Fig. 5a) by revolution 4pi-Analysisv1.6.0b195 program. It exhibits narrow range of particle size distribution $(2-8 \mathrm{~nm})$, with mean value and standard deviation of $4.92 \pm 1.38 \mathrm{~nm}$, and polydispersity index (PDI) 0.279 indicating particles monodispersity. The crystalline structure of AgNPs is shown in Fig. 5c. The diffraction of AgNPs is shown in Fig. 5d.

\subsection{Particle size distribution and zeta potential}

Particle size distribution of AgNPs was measured by DLS ( $Z$-average) and found to be $5.6 \pm 1.4 \mathrm{~nm}$ as shown in Fig. 6. In order to insure the accuracy of the results, the particle size distribution and PDI of the nanocomposite were analyzed again by DLS. The mean particle size of DLS is larger than $\approx 14 \%$ the particle size measured by HRTEM. The obtained results by DLS were compared to those obtained from HRTEM and listed in Table I. However, the DLS depends on the hydrodynamic size while HRTEM depends on the physical size. Thus, the DLS bias tends to larger size fractions [46]. The dispersity is the measure of the heterogeneity of particles' sizes in the medium. The PDI calculated is 0.334 which clarifies monodispersity of nanoparticles [47]. Zeta potential was determined for $\mathrm{PVP}-\mathrm{Ag}$ nanocomposite and found to be $-2.88 \mathrm{mV}$. However, NPs were well-dispersed in the composite (as shown in the TEM micrographs) in spite of their low zeta potential. This is may be attributed to the stabilizing effect of the large molecular weight of PVP to AgNPs through steric stabilization as mentioned by Elbaz et al. [48]. The AgNPs produced by reduction via the $\mathrm{NaBH}_{4}$ are stabilized by the capping effect of PVP. The capping mechanism can be interpreted in terms of the hydrophilic amide groups and the hydrophobic vinyl groups of the PVP. The AgNPs are tied up with the amide groups of PVP through their strong affinity of $\mathrm{N}$ and $\mathrm{O}$ atoms for transition metals. In the same time, the hydrophobic vinyl backbone surrounds the AgNPs to prevent their aggregations. Therefore, PVP plays an important role in controlling the shape and size of AgNPs [24].

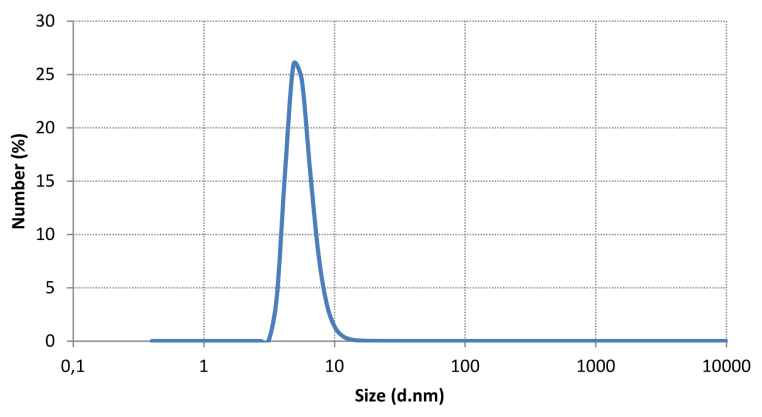

Fig. 6. Dynamic light scattering size distribution graph of the AgNPs.

TABLE I

Comparison between HRTEM and DLS for AgNPs as indicated by the mean particle size ( $\mathrm{nm})$, standard deviation (S.D.) and the polydispersity index (PDI).

\begin{tabular}{c|c|c|c}
\hline \hline Test & Mean [nm] & S.D. [d.nm] & PDI \\
\hline HT-TEM & 4.922 & 1.375 & 0.279 \\
DLS & 5.618 & 1.427 & 0.334
\end{tabular}

\subsection{Inhibition of microbial growth}

The effect of PVP-Ag nanocomposite $(100 \mu \mathrm{g} / \mathrm{mL})$ on the bacterial and fungal growth was examined for different contact times $(1,1.5,2,3 \mathrm{~h})$. The nanocomposite showed $100 \%$ elimination of the microorganisms with $100 \mathrm{\mu g} / \mathrm{mL}$ and shaking $250 \mathrm{rpm}$ and represented in Table II. Four different concentrations of the nanocomposite were examined at $2 \mathrm{~h}$ contact time towards the bacterial and fungal growth. The results are listed in Table III. Surprisingly, all Gram-positive, Gram-negative and fungus were totally killed even by using minimum concentration of the nanocomposite $(25 \mu \mathrm{g} / \mathrm{mL})$.

Few studies have reported the antimicrobial activity of $\mathrm{PVP}-\mathrm{AgNPs}$ by determining minimal inhibitory concentration (MIC) values against $S$. aureus, $P$. aeruginosa and $C$. albicans. In comparison to other studies, our results show superior antimicrobial activity. Bhati et al. [20] determined the MIC values of PVP coated AgNPs with particle size 10-30 nm (prepared by biological method) against $S$. aureus and $P$. aeruginosa as $46 \mu \mathrm{g} / \mathrm{mL}$ 
and against $C$. albicans as $23 \mu \mathrm{g} / \mathrm{mL}$. Dey et al. [49] evaluated the MIC value of $\mathrm{PVP}-\mathrm{AgNPs}$ with particle size $54 \mathrm{~nm}$ against $S$. aureus as $67.41 \mu \mathrm{g} / \mathrm{mL}$. Crespo et al. [15] prepared PVP-AgNPs with mean particle size $4.8 \pm 3.0 \mathrm{~nm}$ whereas larger particles between $7 \mathrm{~nm}$ and $25 \mathrm{~nm}$ were found in a lesser amount. The MIC values of $\mathrm{PVP}-\mathrm{Ag} \mathrm{NPs}$ against $S$. aureus and $P$. aeruginosa were evaluated as $100 \mathrm{\mu g} / \mathrm{mL}$ and $200 \mu \mathrm{g} / \mathrm{mL}$, respectively.

TABLE II

Effect of different contact times with the nanocomposite $(100 \mathrm{\mu g} / \mathrm{mL})$ on the bacterial and fungal growth.

\begin{tabular}{c|c|c|c|c}
\hline \hline Bacterial strain & \multicolumn{3}{|c}{ Contact time $[\mathrm{h}]$} \\
\cline { 2 - 4 } & 1 & 1.5 & 2 & 3 \\
\hline Pseudomonas aeruginosa $\left(4.2 \times 10^{6} \mathrm{CFU} / \mathrm{ml}\right)$ & $\mathrm{ND}$ & $\mathrm{ND}$ & $\mathrm{ND}$ & $\mathrm{ND}$ \\
Staphylococcus aureus $\left(3.7 \times 10^{6} \mathrm{CFU} / \mathrm{ml}\right)$ & $\mathrm{ND}$ & $\mathrm{ND}$ & $\mathrm{ND}$ & $\mathrm{ND}$ \\
Candida albicans $\left(5.3 \times 10^{6} \mathrm{CFU} / \mathrm{ml}\right)$ & $\mathrm{ND}$ & $\mathrm{ND}$ & $\mathrm{ND}$ & $\mathrm{ND}$
\end{tabular}

TABLE III

Effect of different concentrations at contact time $(2 \mathrm{~h})$ on the bacterial and fungal growth.

\begin{tabular}{c|c|c|c|c}
\hline \hline \multirow{2}{*}{ Bacterial strain } & \multicolumn{3}{|l}{ PVP-Ag nanocom- } \\
\cline { 2 - 5 } & posite doses $\left[\frac{\mu \mathrm{g}}{\mathrm{mL}}\right]$ \\
\cline { 2 - 5 } & 25 & 50 & 75 & 100 \\
\hline Pseudomonas aeruginosa $\left(6.2 \times 10^{6} \mathrm{CFU} / \mathrm{ml}\right)$ & $\mathrm{ND}$ & $\mathrm{ND}$ & $\mathrm{ND}$ & $\mathrm{ND}$ \\
Staphylococcus aureus $\left(4.6 \times 10^{6} \mathrm{CFU} / \mathrm{ml}\right)$ & $\mathrm{ND}$ & $\mathrm{ND}$ & $\mathrm{ND}$ & $\mathrm{ND}$ \\
Candida albicans $\left(3.4 \times 10^{6} \mathrm{CFU} / \mathrm{ml}\right)$ & $\mathrm{ND}$ & $\mathrm{ND}$ & $\mathrm{ND}$ & $\mathrm{ND}$
\end{tabular}

\subsection{Cytotoxicity}

Cytotoxicity was investigated against BJ1 cell line after $48 \mathrm{~h}$ of incubation with the nanocomposite. The cells cytotoxicity was $18.5 \%$, which demonstrate the biocompatibility behavior of the nanocomposite.

\section{Conclusion}

PVP-Ag nanocomposite with uniform monodispersed stabilized spherical AgNPs $(\approx 5 \mathrm{~nm})$ was synthesized by simple, economical and rapid reduction method using $\mathrm{NaBH}_{4}$ and PVP. PVP helped controlling the nanoparticles size and distribution through its capping and stabilizing effects, preventing the agglomeration and precipitation of the nanoparticles. Interestingly, $100 \%$ elimination of the Gram-positive, Gram-negative bacteria, and fungi were detected using as low as $25 \mu \mathrm{g} / \mathrm{mL}$ concentration of the nanocomposite prepared beside its biocompatibility behavior toward BJ1 normal cells. Finally, this work is considered as a first step for production of low cost bandages for wound burn treatment and all of the provided studies are complementary to future work.

\section{Acknowledgments}

This work was funded by Science and Technology Development Fund STDF (grant number 12645).

\section{Compliance with ethical standards and conflicts of interest}

The research carried out within this work did not involve human participants and/or animals. The authors declare that they have no conflict of interest.

\section{References}

[1] R. Cristescu, A. Visan, G. Socol, A.V. Surdu, A.E. Oprea, A.M. Grumezescu, M.C. Chifiriuc, R.D. Boehm, D. Yamaleyeva, M. Taylor, R.J. Narayan, D.B. Chrisey, Appl. Surf. Sci. 374, 290 (2016).

[2] V.W.L. Ng, J.M.W. Chan, H. Sardon, R.J. Ono, J.M. Garcia, Y.Y. Yang, J.L. Hedrick, Adv. Drug Deliv. Rev. 78, 46 (2014).

[3] M.K. Rai, S.D. Deshmukh, A.P. Ingle, A.K. Gade, J. Appl. Microbiol. 112, 841 (2012).

[4] V.K. Sharma, R.A. Yngard, Y. Lin, Adv. Coll. Interface Sci. 145, 83 (2009).

[5] I. Sondi, B. Salopek-Sondi, J. Coll. Interface Sci. 275, 177 (2004).

[6] R. Bryaskova, D. Pencheva, S. Nikolov, T. Kantardjiev, J. Chem. Biol. 4, 185 (2011).

[7] J.J. Castellano, S.M. Shafii, F. Ko, G. Donate, T.E. Wright, R.J. Mannari, W.G. Payne, D.J. Smith, M.C. Robson, Int. Wound J. 4, 114 (2007).

[8] X. Chen, H.J. Schluesener, Toxicol. Lett. 176, 1 (2008).

[9] P. Van Dong, C.H. Ha, L.T. Binh, J. Kasbohm, Int. Nano Lett. 2, 9 (2012).

[10] K.C. Song, S.M. Lee, T.S. Park, B.S. Lee, Kor. J. Chem. Eng. 26, 153 (2009).

[11] Q. Zhang, N. Li, J. Goebl, Z. Lu, Y. Yin, J. Am. Chem. Soc. 133, 18931 (2011).

[12] E. Silva, S.M. Saraiva, S.P. Miguel, J.I. Correia, J. Nanopart. Res. 16, 2726 (2014).

[13] Y.A. Krutyakov, A.A. Kudrinskiy, A.Y. Olenin, G.V. Lisichkin, Russ. Chem. Rev. 77, 233 (2008).

[14] D. Pencheva, R. Bryaskova, T. Kantardjiev, Mater. Sci. Eng. C 32, 2048 (2012).

[15] J. Crespo, J. Garcia-Barrasa, J.M. Lopez-deLuzuriaga, M. Monge, M.E. Olmos, Y. Saenz, C. Torres, J. Nanopart. Res. 14, 1281 (2012).

[16] N.A. Zulina, I.M. Pavlovetc, M.A. Baranov, V.O. Kaliabin, I.Y. Denisyuk, Appl. Phys. A 123, 39 (2017).

[17] Z. Zhang, B. Zhao, L. Hu, J. Solid State Chem. 121, 105 (1996).

[18] A.K. Singh, R. Tiwari, V. Kumar, P. Singh, S.K. Riyazat Khadim, A. Tiwari, V. Srivastava, S.H. Hasan, R.K. Asthana, J. Photochem. Photobiol. B Biol. 166, 202 (2017)

[19] A. Kushwaha, V.K. Singh, J. Bhartariya, P. Singh, K. Yasmeen, Eur. J. Exp. Boil. 5, 65 (2015).

[20] D. Bhatia, A. Mittal, D.K. Malik, 3 Biotech. 6, 196 (2016).

[21] K. Mallick, M.J. Witcomb, M.S. Scurrell, J. Mater. Sci. 39, 4459 (2004).

[22] N.A. Zulina, I.M. Pavlovetc, M.A. Baranov, I.Y. Denisyuk, Opt. Laser Technol. 89, 41 (2017). 
[23] O.S. Oluwafemi, T. Mochochoko, A.J. Leo, S. Mohan, D.N. Jumbam, S.P. Songca, Mater. Lett. 185, 576 (2016).

[24] Ž. Jovanović, A. Krklješ, S. Tomić, V. MiškovićStanković, S. Popović, M. Dragašević, Z. KačarevićPopović, in: Trends in Nanophysics, Series Engineering Materials, Eds. V. Barsan, A. Aldea, 2010, p. 315.

[25] H. Jiang, K.-S. Moon, Z. Zhang, S. Pothukuchi, C.P. Wong, J. Nanopart. Res. 8, 117 (2008).

[26] K. Sahayaraj, S. Rajesh, in: Sci. Against Microb. Pathog. Commun. Curr. Res. Technol. Adv. Ed. A. Méndez-Vilas, 2011, p. 228.

[27] S. Chernousova, M. Epple, Angew. Chem. Int. Ed. 52, 1636 (2013).

[28] A.J. Christy, A. Kevin, L.C. Nehru, M. Umadevi, Int. J. Chem. Tech. Res. 7, 1191 (2015).

[29] D.V. Goia, J. Mater. Chem. 14, 451 (2004).

[30] C. Marambio-Jones, E.M.V. Hoek, J. Nanopart. Res. 12, 1531 (2010).

[31] O. Lyutakov, Y. Kalachyova, A. Solovyev, S. Vytykacova, J. Svanda, J. Siegel, P. Ulbrich, V. Svorcik, J. Nanopart. Res. 17, 120 (2015).

[32] M.A. Moharram, S.K.H. Khalil, H.H.A. Sherif, W.A. Khalil, Spectrochim. Acta Part A Mol. Biomol. Spectrosc. 126, 1 (2014).

[33] H. Huang, Q. Yuan, X. Yang, Coll. Surf. B Biointerfaces 39, 31 (2004).

[34] O. Choi, K.K. Deng, N.J. Kim, L. Ross, R.Y. Surampalli, Z. Hu, Water Res. 42, 3066 (2008).

[35] G.A. Martínez-Castanón, N. Nino-Martínez, F. Martínez-Gutierrez, J.R. Martínez-Mendoza, F. Ruiz, J. Nanoparticle Res. 10, 1343 (2008).

[36] Y.-K. Twu, Y.-W. Chen, C.-M. Shih, Powder Technol. 185, 251 (2008).
[37] D. Wei, W. Sun, W. Qian, Y. Ye, X. Ma, Carbohydr. Res. 344, 2375 (2009).

[38] H.V. Tran, L.D. Tran, C.T. Ba, H.D. Vu, T.N. Nguyen, D.G. Pham, P.X. Nguyen, Coll. Surf. A Physicochem. Eng. Asp. 360, 32 (2010).

[39] X.G. Li, I. Kresse, J. Springer, J. Nissen, Y.L. Yang, Polymer 42, 6859 (2001)

[40] Y. Sun, X. Wang, Y. Lu, L. Xuan, S. Xia, W. Feng, X. Han, Chem. Res. Chin. Univ. 30, 703 (2014).

[41] J.R. Mohanty, S.N. Das, H.C. Das, S.K. Swain, Fibers Polym. 15, 1062 (2014).

[42] C.M. Laot, E. Marand, H.T. Oyama, Polymer 40 , 1095 (1999)

[43] B. Liang, Y. Xie, Z. Fang, E.P. Tsang, J. Nanopart. Res. 16, 2485 (2014).

[44] H.-D. Wu, I.-D. Wu, F.-C. Chang, Polymer 42, 555 (2001).

[45] M.T. Ansari, V.B. Sunderland, Arch. Pharm. Res. 31, 390 (2008).

[46] S.A. Cumberland, J.R. Lead, J. Chromatogr. A 1216, 9099 (2009)

[47] K. Dziendzikowska, J. Gromadzka-Ostrowska, A. Lankoff, M. Oczkowski, A. Krawczyńska, J. Chwastowska, M. Sadowska-Bratek, E. Chajduk, M. Wojewódzka, M. Dušinská, M. Kruszewski, J. Appl. Toxicol. 32, 920 (2012).

[48] N.M. Elbaz, L. Ziko, R. Siam, W. Mamdouh, Nat. Publ. Gr. 6, 30729 (2016).

[49] A. Dey, A. Dasgupta, V. Kumar, A. Tyagi, A. Kamra Verma, Int. Nano Lett. 5, 223 (2015). 